\title{
Implementation of sustainable development on the example of the concept of eco-city
}

\author{
*Marcin Leźnicki, **Aleksandra Lewandowska \\ Nicolas Copernicus University, \\ *Department of Bioethics and Moral Philosophy, Fosa Staromiejska 1a, 87-100 Toruń, Poland \\ e-mail: lemahr@umk.pl \\ ** Department of Urban Studies and Regional Development, Lwowska 1, 87-100 Toruń, Poland \\ e-mail: amal@doktorant.umk.pl
}

\begin{abstract}
The paper is to present the issue of implementation of sustainable development on the example of eco-city. It highlights the complexity and multi-faceted nature of the phenomenon and notion of eco-city within its different aspects. This issue is discussed in an interdisciplinary manner and combines humanistic and scientific approaches. Hence, the authors of the above text aimed to characterise sustainable development from the theoretical as well as practical perspective. Therefore this paper has two main objectives. The first objective is to analyze the concept of eco-city and guidelines for eco-city development based on the concept of sustainability. The second objective of the paper is to compare assumptions of the concept with contemporary eco-city projects. Whilst the former includes the vision, beginnings and development of eco-cities, the latter is based on the results of the analysis of 8 different eco-city projects.
\end{abstract}

Key words: eco-city, sustainable development, urban sustainable development, eco-urbanism, eco-architecture, eco-aesthetics, ecological infrastructure, industrial ecology.

\section{Introduction}

Currently, there are nearly 3 billion people living in cities. The UN estimates that by 2050 it will be more than $2 / 3$ of the world population (UN 2012). At the end of 2010 23.3 million people lived in 903 Polish towns, i.e. $60.9 \%$ of the population (GUS 2012). In Europe already $76 \%$ of the population lives in cities. So the city became the main arena of life, market for supply and demand. Although cities are the engines of growth rapid industrialisation has been accompanied by increased use of natural resources and growing energy consumption, which have contributed to increased emission of greenhouse gases and generation of waste. This has led to recognition of the potentially adverse environmental impact of urban development and to inclusion of cities in the environmental sustainability dis- course. For these reasons the need to create a new concept of a city was recognised; one that would be consistent with the requirements of a sustainable development.

During the last decade or so the interest in the idea of 'green', 'sustainable', 'compact', 'environmental' and 'ecological' cities has been steadily increasing. Evolving in this cultural milieu, this exploration of a theory of 'ecocity' has been influenced by various writers and theorists, whom we have tried to acknowledge throughout the article.

This paper has two main objectives. The first objective is to analyze the concept of eco-city and guidelines for ecocity development based on the concept of sustainability. The second objective of the paper is to compare assumptions of the concept with contemporary eco-city projects. 


\section{Philosophical and theoretical basis of the concept of eco-city}

The postulate for creating eco-cities, i.e. organic and symbiotic cities where man could and should live in harmony with nature, is nothing new in human history. We can see it in the early works of ancient philosophers of Western civilization as well as of oriental thinkers.

Already Plato (Lane 2012) suggested an idea of a republic (i.e. polis) as eco-republic whose strong spiritual bonds connect man with the surrounding natural world. Further development of the philosophical concept of ecocity came from Aristotle, who developed this project based on broader reflection on physics, and more precisely, works from the scope of natural sciences. Not only Plato and Aristotle were favorably disposed to the eco-city project but even earlier philosophers perceived human relationships with nature as spiritual experience. This in turn led to questions about the formula of a city, where people could live the best. In response to these questions there gradually began to appear more eco-polis concepts, which supported the potential of eco-urbanism, eco-architecture, and as Gernot Böhme (2002) emphasizes eco-aesthetics.

On the other hand, Charles Goldblum, Lee Dong, Tai Chee-Wong, Belinda Yuen (Chee-Wong et al. 2010) point out that already Lao $\mathrm{Zi}$ and Dao De Jing more than 2.500 years ago began to promote Taoist principle: living with balance and harmony. Ming-Dao (1996) explains that Tao is "literally the movement of all life... the total ongoing of the universe," and that to live according to Taoist principles is to go along with this movement, this flow. Taoist thinking, seen for example in China, Taiwan, and Japan, shall adopt as its starting point the universalist optics initially focused on the ecological approach to urban planning, architecture, management. Eco-cities created in the spirit of Taoism should be characterized by harmony with the environment (Lin et al. 2010). The cities should always be treated as ecosystems, in which there are complicated multi-level processes, whereas management of resources and activities should be managed effectively and equivalently, i.e. with the simultaneous recognition and regard for the interests of man, and with the needs of the surrounding us nature (Register 1987; Meadows \& Randers 1992).

Contemporary urban development has been observed since 1933 due to the Athens Charter. This document contains a criticism of the then existing state of cities, assesses the reasons for this, as well as suggests further courses of action to improve the living conditions of the urban population (Solarek 2011).

70 years later the New Charter of Athens was created which was addressed to urban planners and those responsible for planning processes in Europe. The document was divided into two parts. The first part was more theoretical and contained the definition of a new model of the Euro- pean city. The second part focused on the problems and challenges namely in social, political, economic, technological changes and changes directly concerning urban environmental (Piertuszewski \& Lodziak 2011).

In 1996, the UN convened the Second Global Conference on Human Settlements (Habitat II). Also known as the City Summit, it focused on the importance of sustainable urban development. Selected experts said that the basis for building sustainable cities was the appropriate urban design or redesign. Strong emphasis was also placed on social participation and partnership with local authorities in the planning and development of sustainable cities (Mierzejewska 2008). These issues also contributed to the formation of the concept of eco-city.

\section{Eco-city definitions}

Modern eco-city ideology directly originates from Howard's theory of Garden City. The theory of Garden City reveals the ecological charms of harmonious development of a city and nature. A good example of such development is the Letchworth Garden City in England designed by Ebenezer Howard and built in 1903. Howard was the creator of the garden city idea based on the theory of three magnets, which addressed the question 'Where will the people go?', the choices being 'Town', 'Country' or 'Town-Country' (Howard 1902). He wanted to combine advantages of living in a city with those of being in a countryside, eliminating at the same time their disadvantages. Now, after nearly a century, it still remains one of the most welcoming environments to live in (Wang et al. 2002).

The term 'eco-city' is often traced to Richard Register's (1987) book, Ecocity Berkeley: Building cities for a healthy future. Register describes a city where human beings can exist in harmony with nature therefore greatly reducing their ecological footprint. David Engwicht (1992) published Towards an Eco-City, in which he explains how city planners virtually eliminated human interactions by building more roads, shopping malls and increasing dense traffic. For him, a city is a place for inventions to maximise exchange and minimise travel distance (Engwicht 1993).

Since then many definitions of 'eco-city' were created. A working definition of 'eco-city' as adopted by Ecocity Builders and the International Ecocity Standards advisory team (2010), is: "An Ecocity is a human settlement modeled on the self sustaining resilient structure and function of natural ecosystems. The ecocity provides healthy abundance to its inhabitants without consuming more (renewable) resources than it produces, without producing more waste than it can assimilate, and without being toxic to itself or neighboring ecosystems. Its inhabitants' ecological impact reflect planetary supportive lifestyles; its social order reflects fundamental principles of fairness, justice and reasonable equity." 
The non-profit organization, Urban Ecology (established in 2012), defines an eco-city as "a human settlement that enables its residents to live a good quality of life while using minimal natural resources." Rodney R. White (2002) describes 'eco-city' as "a city that provides an acceptable standard of living for its human occupants without depleting the ecosystems and biochemical cycles on which it depends" (p. 3) and believes it to be the most durable kind of settlement that people can build. Wang et al. (2002) emphasizes that in the concept of 'eco-city' basic principle of city development is to fully exploit the potential of ecological construction under the present resource environment for the purpose of building an efficient, harmonious, healthy and wealthy city. Eco-city should function in the same way as a natural ecosystem. Undoubtedly, each of these definitions emphasizes that sustainably developing city should be in harmony with nature.

\section{Guidelines for eco-city development based on the concept of sustainability}

Ecocity Builders (2002) define the eco-city development as "a whole systems approach integrating administration, ecologically efficient industry, people's needs and aspirations, harmonious culture, and landscapes where nature, agriculture and the built environment are functionally integrated". Doubtless, the concept of eco-city is consistent with sustainable development. Eco-cities demonstrate that urban growth and development can be a sustainable process and that the concept of sustainable development can be practical in an urban setting. Sustainable development is defined as "development that meets the needs of the present without compromising the ability of future generations to meet their own needs" (World Commission on Environmental Development 1987). The concept is based on three pillars of sustainable development: the environment/ecology, the economy and the social aspect. We can see their reflection in the guidelines for eco-city:

$\Rightarrow$ Ecology (Ecocity Builders 2002):

$\rightarrow$ ecological terms: clean air, safe and reliable water supplies, food, healthy housing and workplaces, municipal services,

$\rightarrow$ industrial ecology in particular industrial metabolism: resource conservation and environmental protection through industrial transition, emphasizing re-use of materials, life-cycle production, renewable energy, efficient transportation,

$\rightarrow$ ecological infrastructure: arranging built structures, open spaces such as parks and plazas, connectors such as streets and bridges, and natural features such as waterways and ridgelines, to maximize accessibility of the city for all citizens, $\rightarrow$ ecological awareness and education: help people understand their place in nature, responsibility for the environment, and help them change their consumption behavior.

$\Rightarrow$ Economy and social aspect (Kline 2000):

$\rightarrow$ economic security: support economic growth and security by addressing essential links, including education, training, environmental soundness and occupational safety,

$\rightarrow$ enhanced quality of life: improve people's quality of life by addressing their yearnings for decent, safe, enjoyable places to live, work and play,

$\rightarrow$ empowerment with responsibility: responsive to the needs of community residents, business people and visitors.

Improvement of the eco-city concept has led to the emergence of another concept known as U-Eco City. Recent research undertaken by Yigitcanlar (2009) has revealed that " $U-E c o$ City is a new sustainable city form/ type, where ubiquitous technologies have the potential to revolutionise planning, development and management of these new cities" (p. 26).

Although there is no universally acceptable definition of an eco-city, there is some consensus on the basic features of an eco-city amongst the available definitions. The concept of eco-city is closely linked to the concept of sustainable development, and the construction of such cities is identified with the implementation of the following 10 tasks (Roseland 1997):

1. revise land-use priorities to create compact, diverse, green, safe, pleasant, and vital mixed-use communities near transit nodes and other transportation facilities;

2. change transportation priorities to favour foot, bicycle, cart, and transit over cars, and to emphasize "access by proximity";

3. restore damaged urban environments, especially creeks, shore lines, ridgelines, and wetlands;

4. create decent, affordable, safe, convenient, and racially and economically mixed housing;

5. nurture social justice and create improved opportunities for women, color people, and the disabled;

6. support local agriculture and urban greening projects;

7. promote recycling, innovative appropriate technology, and resource conservation while reducing pollution and hazardous wastes;

8. work with businesses to support ecologically sound economic activity while discouraging pollution and waste;

9. support voluntary simplicity and discourage excessive consumption of material goods;

10. increase awareness of the local environment and bioregion through activist and educational projects that increase public awareness of ecological sustainability issues. 
Table 1. Summary of projects analysed

\begin{tabular}{|c|c|c|c|c|c|}
\hline Project & Location & $\begin{array}{c}\text { Area } \\
\text { (ha) }\end{array}$ & Population & Description & Status \\
\hline $\begin{array}{c}\text { Masdar City } \\
\text { (www.masdarcity.ae/en/home) }\end{array}$ & $\begin{array}{l}\text { Abu Dhabi, } \\
\text { United } \\
\text { Arab } \\
\text { Emirates }\end{array}$ & 600 & 40.000 & $\begin{array}{c}\text { Masdar City is aimed to be zero-carbon and } \\
\text { zero-waste, and to provide home and testing } \\
\text { ground for Abu Dhabi's Masdar Initiative, } \\
\text { which aims to develop Abu Dhabi as a major } \\
\text { energy research centre. }\end{array}$ & $\begin{array}{c}\text { Under } \\
\text { construction, } \\
\text { completion } \\
\text { by } 2016\end{array}$ \\
\hline $\begin{array}{c}\text { Hammarby Sjöstad } \\
\text { (http://www.hammarbysjostad. } \\
\text { se/) }\end{array}$ & $\begin{array}{l}\text { Stockholm, } \\
\text { Sweden }\end{array}$ & 200 & 20.000 & $\begin{array}{l}\text { In New Stockholm district strong efforts have } \\
\text { been made to close the material and energy } \\
\text { cycle. When complete the development } \\
\text { will have about } 10.000 \text { residential units and } \\
350.000 \mathrm{~m}^{2} \text { of commercial space. }\end{array}$ & $\begin{array}{l}\text { Mostly } \\
\text { completed }\end{array}$ \\
\hline $\begin{array}{l}\text { Western Harbour, Bo01 } \\
\text { (http://www.malmo.se/English/ } \\
\text { Sustainable-City-Development/ } \\
\text { Bo01---Western-Harbour.html) }\end{array}$ & $\begin{array}{l}\text { Malmö, } \\
\text { Sweden }\end{array}$ & 160 & 10.000 & $\begin{array}{l}\text { This district of Malmo is built on reclaimed } \\
\text { industrial land and has room for } 600 \\
\text { dwellings, offices, shops and other services. } \\
\text { The development of the district began with } \\
\text { the European Housing Expo that was held in } \\
\text { Malmo in } 2001 .\end{array}$ & Completed \\
\hline $\begin{array}{c}\text { Tianjin Eco-City } \\
\text { (http://www.tianjinecocity.gov. } \\
\text { sg/) }\end{array}$ & China & 3.400 & 350.000 & $\begin{array}{c}\text { Tianjin Eco-city is a collaborative project } \\
\text { between the Chinese and Singaporean } \\
\text { governments, which is environmentally- } \\
\text { friendly and resource-efficient. The project } \\
\text { will be underpinned by educational options } \\
\text { and stakeholder engagement to encourage low } \\
\text { energy living. }\end{array}$ & $\begin{array}{l}\text { Under } \\
\text { construction, } \\
\text { completion } \\
\text { by } 2020\end{array}$ \\
\hline $\begin{array}{c}\text { EcoBay } \\
\text { (http://inhabitat.com/schmidt- } \\
\text { hammer-lass-architects-ecobay/) }\end{array}$ & Estonia & 48 & 6.000 & $\begin{array}{l}\text { Ecobay is tranquil and serene overlooking } \\
\text { the Baltic Sea. The city is a mixed-use } \\
\text { development project that will be a self- } \\
\text { sustaining community that has everything it } \\
\text { needs: housing, shopping districts, schools, } \\
\text { and daycare facilities. }\end{array}$ & $\begin{array}{c}\text { Under } \\
\text { construction }\end{array}$ \\
\hline $\begin{array}{c}\text { Logrono Montecorvo } \\
\text { (http://www.dezeen. } \\
\text { com/2008/09/27/logrono- } \\
\text { montecorvo-eco-city-by-mvrdv/) }\end{array}$ & $\begin{array}{l}\text { La Rioja, } \\
\text { Spain }\end{array}$ & 56 & no data & $\begin{array}{l}\text { Logroño Montecorvo is a zero-carbon town } \\
\text { in which residents use only solar and wind } \\
\text { energy generated on site. The buildings will } \\
\text { occupy } 10 \% \text { of the site, with the remaining } \\
\text { space used for energy production and as } \\
\text { a public park. }\end{array}$ & $\begin{array}{c}\text { Under } \\
\text { construction }\end{array}$ \\
\hline $\begin{array}{c}\text { Xeritown } \\
\text { (http://www.X-architects. } \\
\text { com/architecture. } \\
\text { php?architects=projects) }\end{array}$ & $\begin{array}{l}\text { Abu Dhabi, } \\
\text { United } \\
\text { Arab } \\
\text { Emirates }\end{array}$ & 24 & no data & $\begin{array}{l}\text { Xeritown is located in Dubailand, a new } \\
\text { extension of the city towards the inland desert, } \\
\text { which will be environmentally neutral. The } \\
\text { project is designed so that the cool sea breeze } \\
\text { is sucked into the town and the hot desert } \\
\text { breeze is blocked out. }\end{array}$ & $\begin{array}{c}\text { Under } \\
\text { construction }\end{array}$ \\
\hline $\begin{array}{l}\text { Sonoma Mountain Village } \\
\text { (http://www. } \\
\text { sonomamountainvillage.com) }\end{array}$ & $\begin{array}{l}\text { Northern } \\
\text { California, } \\
\text { USA }\end{array}$ & 200 & no data & $\begin{array}{c}\text { Sonoma Mountain Village is a mixed-use } \\
\text { development on a former industrial site } \\
\text { in California, solar-powered, zero-waste } \\
\text { community under development by Codding. } \\
\text { The project is only the fourth in the world, } \\
\text { endorsed by the prestigious international One } \\
\text { Planet Communities program. }\end{array}$ & $\begin{array}{c}\text { Under } \\
\text { construction }\end{array}$ \\
\hline
\end{tabular}


From environmental sustainability perspective, an ecocity should be in balance with nature, with a minimum consumption of energy, water and food, with a minimum production of carbon dioxide and other greenhouse gases that cause atmospheric and water pollution. However, in order to ensure sustainable development, which requires a balance between environmental/ecological, social and economic sustainability, the environmental features referred to above should be acceptable to people and should be in harmony with their aspirations for economic development.

\section{Analysis of contemporary eco-city projects}

Previously we presented theoretical assumptions of the concept of eco-city. Now we will analyze selected projects that refer to this concept. Since approximately 2000 a number of ambitious plans began to emerge for brand new sustainable urban districts and cities. Famous examples include Masdar City in Abu Dhabi, United Arab Emirates, EcoBay in Island and Hammarby Sjöstad in Stockholm, Sweden, as well as Chinese projects, Tianjin EcoCity and Caofedian Eco-City. To date, there have been few systematic surveys of eco-cities. In 2009, findings of the global survey were presented and some 79 identified ecocity initiatives, including the aforementioned ones, were compared (Joss 2010).

This paper presents only 8 eco-city projects (Table 1 ), in order to reflect their spatial differentiation. We then shortlisted projects on the basis of their type, size and ambition. Table 1 lists each of the selected projects and provides basic information about them. We took into account European as well as Asian and American projects. European projects of eco-cities are much smaller and more modest in comparison to, for example, Chinese Tianjin Eco-City. Each of the projects, despite implementing a common concept, puts an emphasis on different aspects of sustainability.

For instance, Masdar City is presented as a vehicle for developing a renewable energy industry in Abu Dhabi, therefore emphasizes mostly economic issues of sustainable development. In EcoBay issues related to protection of the environment dominate because much of the city will be located in areas by the Baltic Sea and the site has huge potential if one takes into account its proximity to the city centre and the Nature 2000 nature reserve. On the other hand, for the two Swedish projects one of the basic aims is to reduce by $50 \%$ the negative environmental impact compared to standard neighborhoods of the nineties. In planning of the project, one of the main guiding principles was to adopt a holistic approach towards creating and designing a livable, efficient and compact city, which would be developed in an ecologically sound and environmentally sustainable manner (Ma 2009).
In all of the 8 projects the principles of sustainable development and the basic guidelines for eco-city are implemented. The common features of the projects are: reduced air pollution, revised land-use priorities to create compact city, promotion of recycling and innovative technologies as well as the use of energy from renewable sources. Note, however, that not all projects address social issues. Attention is paid to a high quality of life for urban population but residents do not receive jobs, in particular in Asian projects. Furthermore, problems of nurturing social justice and creating improved opportunities for women, elderlies, minorities and the disabled are overlooked.

\section{Conclusion}

The eco-city projects have the potential to affect social interactions and engage citizens in the management of a urban ecosystem. They are engaging for the community because they are about measuring the quality of life.

The implementation of a sustainable program requires cooperation between municipality, private firms, organizations and individuals. The process should be supported by demonstration projects. It would be premature to speculate on the success or failure of 'eco-cities', as most projects are still at the planning stage or 'under construction'. Therefore, eco-city projects carry out educational functions as well as are heralds of exploring a partnership between urban planning and ecology.

Interdisciplinary and multidisciplinary perspectives will ensure a better understanding of the process of urbanisation in the spirit of the concept of eco-city. Only in the long term, we can assess the real impact of the concept of sustainable development on urban planning. Therefore, we have yet to wait for specific conclusions on the ecocity projects.

\section{References}

Böhme G., 2002, Filozofia i estetyka przyrody w dobie kryzysu środowiska naturalnego, [Philosophy and aesthetics of nature at the time of environmental], Wyd. Oficyna Naukowa, Warszawa.

Chee-Wong T., Goldblum C., Belinda J., 2010, Spatial Planning for a Sustainable Singapore, Springer, Singapore.

EcoBay, http://inhabitat.com/schmidt-hammer-lass-architects-ecobay/, [Accessed 20.10.2013].

Ecocity Builders, 2002, http://www.ecocitybuilders.org/ why-ecocities/the-solution/ guidelines-for-ecocity-development/, [Accessed 21.10.2013].

Ecocity Builders and the International Ecocity Standards advisory team, 2010, http://www.ecocitybuilders.org/ 
why-ecocities/the-solution/ecocity-definition/, [Accessed 21.10.2013].

Engwicht D., 1992, Towards an Eco-City: Calming the Traffic, Envirobook, Sydney.

Engwicht D., 1993, Reclaiming our Cities and Towns: Better Living with Less Traffic, New Society Publishers, Gabriola Island, BC.

Główny Urząd Statystyczny [Central Statistical Office], 2012, Miasta w liczbach [Cities in numbers], Warszawa.

Hammarby Sjöstad, http://www.hammarbysjostad.se/, [Accessed 20.10.2013].

Howard E., 1902, Garden City of To-Morrow, Faber and Faber, London.

Joss S., 2010, Eco-cities — a global survey 2009, WIT Transactions on Ecology and the Environment, 129: 239-250.

Kline E., 2000, Planning and creating eco-cities: indicators as a tool for shaping development and measuring progress, Local Environment 5(3): 343-350.

Lane M., 2012, Eco-Republic: What the Ancients Can Teach Us about Ethics, Virtue, and Sustainable Living, Princeton University Press, Princeton-Oxford.

Lin C., Feng L. \& Hua-Feng D., 2010, Harmonious Development between Urban Economy and Eco-environment in Huaibei City, China, Urban Environment \& Urban Ecology 4: 6-8.

Logrono Montecorvo, http://www.dezeen.com/2008/09/27/ logrono-montecorvo-eco-city-by-mvrdv/, [Accessed 19.10.2013].

Ma Q., 2009, Eco-City and eco-planning in China: taking an example for Caofeidian Eco-City, Proceedings of the 4th International Conference Forum on Urbanism, Amsterdam/Delf: 511-520.

Masdar City, www.masdarcity.ae/en/home, [Accessed 22.10.2013]

Meadows D. D. \& Randers J., 1992, Beyond the Limits: Confronting Global Collapse, Envisioning a Sustainable Future, Earthscan Publications, London.

Mierzejewska L., 2008, Zrównoważony rozwój miasta: aspekty planistyczne [Sustainable development of a city: Planning aspects], Biuletyn Instytutu Geografii Społeczno-Ekonomicznej i Gospodarki Przestrzennej Uniwersytetu im. Adama Mickiewicza w Poznaniu, Seria Rozwój Regionalny i Polityka Regionalna [Bulletin of the Institute of Socio-Economic Geography and
Spatial Management, the Adam Mickiewicz University in Poznań, Series: Regional Development and Regional Policy] 5: 49-70.

Ming-Dao D., 1996, Everyday Tao: Living with Balance and Harmony, HarperOne, San Francisco, CA.

Piertuszewski J. \& Lodziak A., 2011, Uwarunkowania zewnętrzne - wspólnotowe oraz krajowe podstawy polityki miejskiej [External factors - the community and national basis of urban policy], Gdańsk, http://urzad. pomorskie.eu/res/umwp/dokumenty/polityka_miejska/ polityka_miejska_uwarunkowania_zewnetrzne.pdf, [Accessed 20.01.2013].

Register R., 1987, Ecocity Berkeley: building cities for a healthy future, North Atlantic Books, Berkeley, CA.

Roseland M., 1997, Dimensions of the eco-city, Cities 14(4): 197-202.

Sonoma Mountain Village, http://www.sonomamountainvillage.com/, [Accessed 19.10.2013].

Solarek K., 2011, Współczesne koncepcje rozwoju miasta [Modern concepts of urban development], Kwartalnik Architektury i Urbanistyki [the Quarterly Journal of Architecture and Urban Planning] 56(4): 51-71.

Tianjin Eco-City, http://www.tianjinecocity.gov.sg/, [Accessed 20.10.2013].

United Nations, Department of Economic and Social Affairs, 2012, World Urbanization Prospects The 2011 Revision, New York.

Wang L., Wu H. \& Song H., 2002, A framework of integrating digital city and ecocity. School of Business, Hubei University, Wuhan, China.

Western Harbour, Bo01, http://www.malmo.se/English/ Sustainable-City-Development/Bo01---Western-Harbour.html, [Accessed 19.10.2013].

White R. R., 2002, Building the Ecological City, Woodhead Publishing Ltd, Cambridge.

Word Commission on Environmental Development, 1987, Our Common Future, Oxford University Press, New York.

Xeritown, http://www.X-architects.com/architecture. php?architects=projects, [Accessed 22.10.2013].

Yigitcanlar T., 2009, Ubiquitous eco-cities: a new sustainable city form? Paper presented at the Urban Design Seminar, Gold Coast City Council, Gold Coast, Australia. 